\title{
Dry season and soil texture affect the chemical control of monocotyledonous in sugarcane
}

\author{
Hudson Kagueyama Takano*, Denis Fernando Biffe, Jamil Constantin, \\ Rubem Silvério de Oliveira Junior, Guilherme Braga Pereira Braz, Alexandre Gemelli
}

State University of Maringá, Maringá, Paraná, Brazil.

*Corresponding author, e-mail: hudsontakano@gmail.com

\begin{abstract}
The chemical weed control in sugarcane during the wet season is more effective than the control carried out during the dry season. The objective of this study was to evaluate the efficacy of herbicides in the rainy season and in the dry season in sugarcane crop, and in different soil textural classes. The experiments simulated dry season and rainy season basing on periods of days in which experiment was submitted to irrigation restriction. In each experiment, it was tested 50 and $100 \%$ of the dose of the main herbicides commonly used in sugarcane to control $B$. decumbens, B. plantaginea, P. maximum and D. horizontalis. In general, in dry conditions, as well as varying the soil texture, there are restrictions in the choice of herbicide to be used due to the reduced effectiveness of some treatments in certain situations. In the very-clayey soil, especially in the dry season, the efficacy of herbicides is better, whereas, for the sandy-clay-loam soil in dry conditions, the effectiveness of herbicides is restricted. Thus, this study, despite the great complexity of the variables to be analyzed, permitted to establish guidelines for decision making on the most appropriate herbicide to be applied in each studied condition, in order to control these weed species.
\end{abstract}

Keywords: Brachiaria decumbens, Brachiaria plantaginea, Digitaria horizonthalis, Panicum maximum, pre-emergence

\section{Introduction}

The area under sugarcane crop in Brazil exceeded 9 million hectares and total production was 630 million tons in the 2014/2015 harvest (Conab, 2015). In some regions of Brazil, sugarcane is harvested during the driest period of the year, when there is less rainfall and consequently, less availability of water in the soil. In the sugar-alcohol industry, this period is commonly called the "dry season" (Azania et al., 2006).

The chemical control of weeds in sugarcane carried out in the rainy seasons is more effective when compared to control carried out in the drier seasons, since soil moisture and intense weed metabolism favor the absorption of most of the applied herbicides (Azania et al., 2009). However, due to the extensive harvesting period and the need for control to be carried out at the beginning of the sugarcane growth period, the applications in the dry season are fundamental for maintaining sugarcane yield.

The herbicides amicarbazone, [diuron + hexazinone + sulfometuron], imazapic, isoxaflutole, sulfentrazone, and tebuthiuron have shown more efficient results to these conditions. Due to their more appropriate physicochemical characteristics, such as the high water-solubility and low adsorption capacity in clay minerals and soil organic matter, these herbicides have shown 
successful used to these conditions (Carbonari et al., 2009; Correia et al., 2010; Negrisoli et al., 2011). In these cases, the residual activity of the herbicides selected for the chemical control in conditions of low soil moisture should be enough to keep the crop free from weed infestation until the beginning of the rainy season.

The choice of the herbicide and its application period have been carried out with defined criteria, however, all the necessary variables to maximize the effect of control and reduction of weed interference on sugarcane crop are not included (Kuva et al., 2007). Among the variables that are not taken into account, the better understanding of the herbicide control spectrum, as well as the better using of these products in specific soil moisture situations, may be useful to sustain decisions and make them more judicious when choosing the treatment to be used.

Therefore, the objective of this study was to evaluate the efficacy of herbicides under simulated "wet season" and "dry season" conditions in two soils with distinct texture classes, in order to identify the best herbicide to control monocotyledon weeds in each of these conditions.

\section{Materials and Methods}

Four experiments were carried out in a greenhouse located in Maringá county, Paraná state, from January to May 2013. The experiments included the simulations of the dry season and wet season in each soil textural class. These simulations were based on periods (days), in which irrigation was restricted, in order to artificially simulate the edaphoclimatic conditions that occur in the dry season and in the wet season as previously discussed.

In each experiment 50 and $100 \%$ of the recommended dose of the main herbicides used in sugarcane crop (Table 1 and Table 2) were tested, in order to observe the differences between the residual control of each herbicide, for four weed species (Brachiaria decumbens, Brachiaria plantaginea, Panicum maximum, and Digitaria horizontalis). For the four experiments, the experimental design was a completely randomized design with four replications.

The experimental units were represented by $3 \mathrm{dm}^{3}$ pots. In two experiments, the pots were filled with sandy-clay-loam soil, showing $\mathrm{pH}$ in water $=5.50 ; \mathrm{H}^{+}+\mathrm{Al}^{+3}=3.10 \mathrm{cmol}_{\mathrm{c}} \mathrm{dm}^{-3}, \mathrm{C}=16.00$ $\mathrm{g} \mathrm{dm}^{-3}$; coarse sand $=417 \mathrm{~g} \mathrm{~kg}^{-1}$; fine sand $=662$

Table 1. Herbicide and their respective doses used in the four experiments.

\begin{tabular}{|c|c|c|c|c|}
\hline \multirow{3}{*}{ Treatment } & \multicolumn{4}{|c|}{ Dose (g i.a. hall) $^{-1}$} \\
\hline & \multicolumn{2}{|c|}{$50 \%$} & \multicolumn{2}{|c|}{$100 \%$} \\
\hline & S.C.L. & V.C. & S.C.L. & V.C. \\
\hline \multicolumn{5}{|c|}{ Tested in the wet season and the dry season } \\
\hline 01-Control (without herbicide) & - & - & - & - \\
\hline 02-Amicarbazone & 525.00 & 700.00 & 1050.00 & 1400.00 \\
\hline 03-Clomazone & 0.45 & 0.50 & 0.90 & 1.00 \\
\hline 04-[Diuron+hexazinona] Fl'1 & {$[0.42+0.12]$} & {$[0.59+0.17]$} & {$[0.84+0.24]$} & {$[1.17+0.33]$} \\
\hline $\begin{array}{l}\text { 05-[Diuron+hexazinona+ } \\
\text { sulfometuron] }\end{array}$ & {$[0.51+0.14+0.01]$} & {$[0.69+0.2+0.02]$} & {$[1.03+0.29+0.02]$} & {$[1.39+0.39+0.04]$} \\
\hline 06-Diclosulam & 63.00 & 84.00 & 126.00 & 168.00 \\
\hline 07-Flumioxazin & 87.50 & 87.50 & 175.00 & 175.00 \\
\hline 08-Hexazinona & 0.09 & 0.25 & 0.19 & 0.50 \\
\hline 09-Imazapic & 52.50 & 122.50 & 105.00 & 245.00 \\
\hline 10-Isoxaflutole & 56.26 & 56.26 & 112.50 & 112.50 \\
\hline 11-Sulfentrazone & 0.30 & 0.30 & 0.60 & 0.60 \\
\hline 12-Tebuthiuron & 0.50 & 0.60 & 1.00 & 1.20 \\
\hline \multicolumn{5}{|c|}{ Tested only in the wet season } \\
\hline 13-Ametrina & 1.50 & 2.00 & 3.00 & 4.00 \\
\hline 14-[Diuron+hexazinona] F2² & {$[0.55+0.07]$} & {$[0.97+0.12]$} & {$[1.11+0.13]$} & {$[1.94+0.23]$} \\
\hline 15-Diuron & 0.80 & 1.00 & 1.60 & 2.00 \\
\hline 16-Metribuzin & 0.84 & 0.96 & 1.68 & 1.92 \\
\hline 17-S-metolachlor & 0.72 & 0.96 & 1.44 & 1.92 \\
\hline 18-Trifluralin & 0.27 & 0.53 & 0.53 & 1.07 \\
\hline
\end{tabular}


$\mathrm{g} \mathrm{kg}^{-1}$, silt $=68 \mathrm{~g} \mathrm{~kg}^{-1}$, and clay $=270 \mathrm{~g} \mathrm{~kg}^{-1} . \mathrm{In}$ the other two experiments, the soil was classified as very-clayey, showing $\mathrm{pH}$ in water $=5.50 ; \mathrm{H}^{+}+$ $\mathrm{Al}^{+3}=3.80 \mathrm{cmol}_{\mathrm{c}} \mathrm{dm}^{-3} ; \mathrm{C}=24.10 \mathrm{~g} \mathrm{dm}^{-3}$; coarse sand $=34 \mathrm{~g} \mathrm{~kg}^{-1}$; fine sand $=105 \mathrm{~g} \mathrm{~kg}^{-1}$; silt $=210 \mathrm{~g}$ $\mathrm{kg}^{-1}$ and clay $=685 \mathrm{~g} \mathrm{~kg}^{-1}$. In both cases, the soils were air-dried and sieved before being placed into the pots.

For the sowing, 30 seeds of each weed species per pot were used, and then only the wet season experiments were irrigated. The herbicides were then applied (Figure 1). The pots of the wet season experiments were irrigated daily, maintaining the soil moisture close to the field capacity. The dry season experiments were maintained without irrigation until 60 days after application (DAA) of the treatments aiming at the simulation of the dry season. After this period without irrigation, the pots of these experiments were also submitted to daily irrigation, as described for the wet season experiments. For all experiments, the plants began to emerge only after the beginning of the irrigation, and consequently, the control was evaluated only after this period.
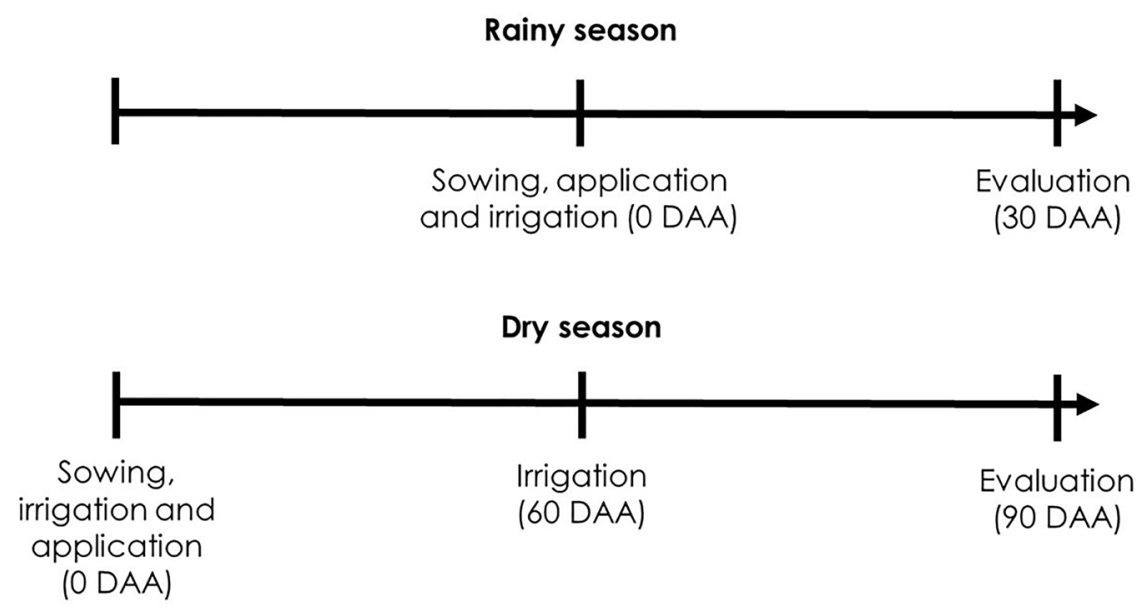

Figure 1. Herbicide applications, evaluations, irrigation, sowing, and resowing during the dry and wet season experiments. DAA = days after application.

In all applications, a $\mathrm{CO}_{2}$-based constant pressure backpack sprayer, equipped with a bar with three XR-110.02 fan type nozzles, spaced $50 \mathrm{~cm}$ apart, under pressure of $2.0 \mathrm{kgf} \mathrm{cm}^{-2}$ was used. These application conditions provided a $200 \mathrm{~L} \mathrm{ha}^{-1}$ application rate. During application, climate conditions for the wet season were: $28^{\circ} \mathrm{C}$; air relative humidity $=68 \%$, and wind speed $=1,2$ $\mathrm{km} \mathrm{h}^{-1}$. For the dry season were: $27^{\circ} \mathrm{C}$; air relative humidity $=66 \%$; and wind speed $=1,1 \mathrm{~km} \mathrm{~h}^{-1}$.

The evaluations were performed on 30 days after irrigation (DAI), through a $0-100 \%$ scale, where $0 \%$ represents null herbicide effect in plants, and $100 \%$ represents their death. The data were submitted to analysis of variance and to the $\mathrm{F}$ test. The means were compared by the Scott-Knott group test at the $10 \%$ probability level.

\section{Results and Discussion}

Brachiaria decumbens

For B. decumbens (Table 2), in the sandy- clay-loam soil, the residual control of all herbicides in the wet season was higher than $95 \%$, except for treatments with diclosulam and trifluralin at $50 \%$ of the recommended dose (Table 2), which under these conditions showed control less than $80 \%$, being considered as unsatisfactory.

On the other hand, in the dry season, few herbicides resulted in effective control of $B$. decumbens, evidencing the difficulty of control when herbicides are applied during periods of low rainfall. Only five herbicides showed satisfactory results ( $\geq 80 \%$ ) when the $100 \%$ of the recommended dose was used, which were clomazone, [diuron + hexazinone + sulfometuron], flumioxazin, diclosulam and isoxaflutole, whereas only 3 herbicides were satisfactory, when $50 \%$ of the dose was applied ([diuron + hexazinone + sulfometuron], flumioxazin and diclosulam). The other treatments showed control levels equal or lower than $60 \%$. 
Table 2. Residual control of Brachiaria decumbens under 50 and $100 \%$ of the herbicides recommended dose for sugarcane crop, in the wet and dry season, in two soil textural classes at $30 \mathrm{DAl}$.

\begin{tabular}{|c|c|c|c|c|c|c|c|c|c|c|c|c|c|c|c|c|}
\hline \multirow{3}{*}{ Treatment } & \multicolumn{8}{|c|}{ Sandy-clay-loam soil } & \multicolumn{8}{|c|}{ Very-clayey soil } \\
\hline & \multicolumn{4}{|c|}{$50 \%$} & \multicolumn{4}{|c|}{$100 \%$} & \multicolumn{4}{|c|}{$50 \%$} & \multicolumn{4}{|c|}{$100 \%$} \\
\hline & \multicolumn{2}{|c|}{ wet } & \multicolumn{2}{|c|}{ dry } & \multicolumn{2}{|c|}{ wet } & \multicolumn{2}{|c|}{ dry } & \multicolumn{2}{|c|}{ wet } & \multicolumn{2}{|c|}{ dry } & \multicolumn{2}{|c|}{ wet } & \multicolumn{2}{|c|}{ dry } \\
\hline 01-Control & 0.0 & d & 0.0 & $b$ & 0.0 & $b$ & 0.0 & C & 0,0 & C & 0,0 & $\mathrm{~b}$ & 0,0 & c & 0,0 & $\mathrm{C}$ \\
\hline 02-Amicarbazone & 100.0 & $a$ & 12.0 & $\mathrm{~b}$ & 100.0 & $a$ & 20.0 & c & 100,0 & $a$ & 100,0 & $a$ & 100,0 & a & 100,0 & $a$ \\
\hline 03-Clomazone & 100.0 & $a$ & 30.0 & $b$ & 100.0 & $a$ & 81.7 & a & 100,0 & $a$ & 100,0 & $a$ & 100,0 & a & 100,0 & $a$ \\
\hline $04-[\mathrm{D}+\mathrm{H}] \mathrm{F}]^{1 /}$ & 100.0 & $a$ & 30.0 & $b$ & 100.0 & $a$ & 48.3 & $b$ & 100,0 & $a$ & 100,0 & $a$ & 100,0 & a & 100,0 & $a$ \\
\hline $05-[\mathrm{D}+\mathrm{H}+\mathrm{S}]^{2 /}$ & 100.0 & $a$ & 76.7 & $a$ & 100.0 & $a$ & 100.0 & $a$ & 100,0 & $a$ & 83,3 & $a$ & 100,0 & a & 100,0 & $a$ \\
\hline 06-Diclosulam & 78.3 & $b$ & 79.3 & $a$ & 97.0 & $a$ & 95.0 & a & 97,7 & $a$ & 87,7 & $a$ & 97,7 & a & 100,0 & $a$ \\
\hline 07-Flumioxazin & 100.0 & $a$ & 90.0 & $a$ & 100.0 & $a$ & 100.0 & a & 100,0 & $a$ & 100,0 & $a$ & 100,0 & a & 100,0 & $a$ \\
\hline 08-Hexazinona & 100.0 & $a$ & 23.3 & $b$ & 100.0 & $a$ & 46.7 & $b$ & 100,0 & $a$ & 20,0 & $\mathrm{~b}$ & 100,0 & a & 78,7 & $b$ \\
\hline 09-Imazapic & 96.7 & $a$ & 25.7 & $b$ & 98.0 & $a$ & 45.0 & $b$ & 78,3 & $b$ & 77,3 & $a$ & 75,3 & $b$ & 73,3 & $b$ \\
\hline 10-Isoxaflutole & 100.0 & $a$ & 11.7 & $b$ & 100.0 & $a$ & 83.3 & a & 100,0 & $a$ & 88,3 & a & 100,0 & $a$ & 100,0 & $a$ \\
\hline 11-Sulfentrazone & 100.0 & $a$ & 16.7 & $b$ & 100.0 & $a$ & 60.0 & $b$ & 100,0 & $a$ & 76,7 & a & 100,0 & $a$ & 100,0 & $a$ \\
\hline 12-Tebuthiuron & 100.0 & $a$ & 10.0 & $b$ & 100.0 & $a$ & 50.0 & $b$ & 100,0 & $a$ & 63,3 & $a$ & 100,0 & $a$ & 100,0 & $a$ \\
\hline 13-Ametrina & 100.0 & $a$ & - & & 100.0 & $a$ & - & & 97,7 & $a$ & - & & 91,0 & a & - & \\
\hline 14-[D+H] F23/ & 100.0 & $a$ & - & & 100.0 & $a$ & - & & 100,0 & $a$ & - & & 100,0 & $a$ & - & \\
\hline 15-Diuron & 100.0 & $a$ & - & & 100.0 & a & - & & 100,0 & $a$ & - & & 100,0 & $a$ & - & \\
\hline 16-Metribuzin & 100.0 & $a$ & - & & 100.0 & $a$ & - & & 100,0 & $a$ & - & & 100,0 & $a$ & - & \\
\hline 17-S-metolachlor & 99.3 & $a$ & - & & 100.0 & $a$ & - & & 100,0 & $a$ & - & & 100,0 & $a$ & - & \\
\hline 18-Trifluralin & 72.7 & $\mathrm{~b}$ & - & & 100.0 & a & - & & 96,0 & $a$ & - & & 100,0 & $a$ & - & \\
\hline$F$ & $230.3^{*}$ & & $17.3^{*}$ & & $180.1^{*}$ & & $12.0^{*}$ & & $216.6^{*}$ & & $25.2^{*}$ & & $255.1^{*}$ & & $12.5^{*}$ & \\
\hline CV (\%) & 5.9 & & 35.6 & & 3.0 & & 23.5 & & 4.8 & & 22.2 & & 7.1 & & 32.3 & \\
\hline
\end{tabular}

* Mean values sharing the same letter do not differ (Scott-Knott test $p<0.10$ ).

$1 /[\mathrm{D}+\mathrm{H}] \mathrm{Fl}=$ [diuron+hexazinona] $\mathrm{Fl}=$ Velpar $\AA ; 2 /[\mathrm{D}+\mathrm{H}+\mathrm{S}]=[$ diuron+hexazinona+sulfometuron]; $3 /[\mathrm{D}+\mathrm{H}] \mathrm{F} 2=[$ diuron+hexazinona $]$ F2=Advance®; DAl: days after irrigation.

In the very-clayey soil, except for imazapic, the residual control of the herbicides in the wet season was very effective, regardless of the used dose. On the other hand, under conditions of water restriction (dry season), lower percentages of control were observed with the application of hexazinone in the $50 \%$ dose and hexazinone and imazapic in the $100 \%$ dose. The herbicides imazapic, sulfentrazone, and tebuthiuron applied at the $50 \%$ dose, despite having unsatisfactory control, did not differ from the best treatments using half the recommended dose.

The low efficacy of imazapic on $B$. decumbens was also observed by Hernandez et al. (2001) in an experiment that evaluated the efficacy of imazapic in soil with or without straw. These authors concluded that imazapic was inefficient for the control of $B$. decumbens under both vegetation cover conditions.

Diuron showed a high control of $B$. decumbens in both sandy and clayey soils, at the doses of $1.60 \mathrm{~kg} \mathrm{ha}^{-1}$ and $3.20 \mathrm{~kg} \mathrm{ha}^{-1}$, respectively (Inove et al., 2014), which was similar to the results found in the present study. These authors also observed a differentiated behavior in the movement of this herbicide between the two types of soils, with a small mobility of the diuron molecules in soil with a sandy texture and restricted mobility in soil texture with a clayey texture.

\section{Panicum maximum}

The sulfentrazone results were not satisfactory even in the wet season with the $100 \%$ dose for the sandy-clay-loam soil, whereas only diclosulam, sulfrentazone, tebuthiuron and trifluralin showed not satisfactory results with the $50 \%$ dose (Table 3 ). In the dry season, only amicarbazone did not show satisfactory control with the $100 \%$ dose, however, with the $50 \%$ dose most herbicides showed poor control, except clomazone, [diuron + hexazinone + sulfometuron], flumioxazin and imazapic, which showed satisfactory control.

The control of P. maximum in very-clayey soils in the wet season was generally greater than $95 \%$ in most treatments with the $100 \%$ dose. Even using only $50 \%$ of the recommended dose, most of the herbicides showed efficacy, except the 
Takano et al. (2017) / Dry season and soil texture affect ...

Table 3. Residual control of Panicum maximum under 50 and $100 \%$ of the herbicides recommended dose for sugarcane crop, in the wet and dry season, in two soil textural classes at 30 DAl.

\begin{tabular}{|c|c|c|c|c|c|c|c|c|c|c|c|c|c|}
\hline \multirow{3}{*}{ Treatment } & \multicolumn{6}{|c|}{ Sandy-clay-loam soil } & \multicolumn{7}{|c|}{ Very clayey soil } \\
\hline & \multicolumn{3}{|c|}{$50 \%$} & \multicolumn{3}{|c|}{$100 \%$} & \multicolumn{3}{|c|}{$50 \%$} & \multicolumn{4}{|c|}{$100 \%$} \\
\hline & wet & & dry & wet & & dry & wet & & dry & wet & & dry & \\
\hline$\overline{01-C o n t r o l}$ & 0.0 & $d$ & $0.0 \mathrm{~b}$ & 0.0 & C & $0.0 \mathrm{c}$ & 0.0 & C & $0.0 \mathrm{c}$ & 0.0 & C & 0.0 & $\mathrm{~b}$ \\
\hline 02-Amicarbazone & 100.0 & $a$ & $73.3 \mathrm{~b}$ & 91.0 & $a$ & $60.0 \mathrm{~b}$ & 100.0 & $a$ & $76.3 \mathrm{~b}$ & 100.0 & $a$ & 83.7 & $a$ \\
\hline 03-Clomazone & 98.6 & $a$ & $100.0 \mathrm{a}$ & 98.7 & $a$ & $96.7 \mathrm{a}$ & 100.0 & $a$ & $100.0 \mathrm{a}$ & 100.0 & $a$ & 100.0 & $a$ \\
\hline $04-[\mathrm{D}+\mathrm{H}] \mathrm{F}^{1 /}$ & 100.0 & $a$ & $64.6 \mathrm{~b}$ & 100.0 & $a$ & $80.0 \mathrm{a}$ & 100.0 & $a$ & $73.3 \mathrm{~b}$ & 100.0 & $a$ & 100.0 & $a$ \\
\hline $05-[\mathrm{D}+\mathrm{H}+\mathrm{S}]^{2 /}$ & 100.0 & $a$ & $99.3 \mathrm{a}$ & 100.0 & $a$ & $99.3 \mathrm{a}$ & 100.0 & $a$ & $99.7 \mathrm{a}$ & 100.0 & $a$ & 99.3 & $a$ \\
\hline 06-Diclosulam & 76.6 & $b$ & $70.0 \mathrm{~b}$ & 96.0 & $a$ & $99.0 \mathrm{a}$ & 94.7 & $a$ & $97.7 \mathrm{a}$ & 99.0 & $a$ & 99.0 & $a$ \\
\hline 07-Flumioxazin & 100.0 & $a$ & $96.6 \mathrm{a}$ & 100.0 & $a$ & $100.0 \mathrm{a}$ & 100.0 & $a$ & $100.0 \mathrm{a}$ & 96.7 & $a$ & 100.0 & $a$ \\
\hline 08-Hexazinona & 100.0 & $a$ & $23.3 \mathrm{c}$ & 100.0 & $a$ & $93.3 \mathrm{a}$ & 100.0 & $a$ & $20.0 \mathrm{C}$ & 100.0 & $a$ & 26.7 & $b$ \\
\hline 09-Imazapic & 100.0 & $a$ & $100.0 \mathrm{a}$ & 100.0 & $a$ & $99.3 \mathrm{a}$ & 83.3 & $\mathrm{~b}$ & $89.3 \mathrm{a}$ & 80.0 & $\mathrm{~b}$ & 99.0 & $a$ \\
\hline 10-Isoxaflutole & 94.6 & $a$ & $66.6 \mathrm{~b}$ & 90.0 & $a$ & $90.0 \mathrm{a}$ & 100.0 & $a$ & $26.7 \mathrm{C}$ & 100.0 & $a$ & 86.7 & $a$ \\
\hline 11-Sulfentrazone & 58.3 & $c$ & $66.6 \mathrm{~b}$ & 71.7 & $\mathrm{~b}$ & $83.3 \mathrm{a}$ & 100.0 & $a$ & $65.0 \mathrm{~b}$ & 100.0 & $a$ & 85.7 & $a$ \\
\hline 12-Tebuthiuron & 73.3 & $b$ & $75.0 \mathrm{~b}$ & 100.0 & $a$ & $99.7 \mathrm{a}$ & 100.0 & $a$ & $26.7 \mathrm{c}$ & 100.0 & $a$ & 86.0 & $a$ \\
\hline 13-Ametrina & 98.0 & $a$ & - & 100.0 & $a$ & - & 90.0 & $a$ & - & 82.0 & $b$ & - & \\
\hline $14-[\mathrm{D}+\mathrm{H}] \mathrm{F} 2^{3 /}$ & 100.0 & $a$ & - & 100.0 & $a$ & - & 100.0 & $a$ & - & 100.0 & $a$ & - & \\
\hline 15-Diuron & 100.0 & $a$ & - & 100.0 & $a$ & - & 100.0 & $a$ & - & 96.7 & $a$ & - & \\
\hline 16-Metribuzin & 100.0 & $a$ & - & 100.0 & $a$ & - & 100.0 & $a$ & - & 100.0 & $a$ & - & \\
\hline 17-S-metolachlor & 96.6 & $a$ & - & 100.0 & $a$ & - & 100.0 & $a$ & - & 99.3 & $a$ & - & \\
\hline 18-Trifluralin & 83.0 & $\mathrm{~b}$ & - & 97.3 & $a$ & - & 73.3 & $\mathrm{~b}$ & - & 95.0 & $a$ & - & \\
\hline $\mathrm{F}$ & $104.7^{*}$ & & $18.1^{*}$ & $99.2^{*}$ & & $17.1^{*}$ & $111.0^{*}$ & & $17.7^{*}$ & $99.9 *$ & & $21.2^{*}$ & \\
\hline CV (\%) & 8.6 & & 33.7 & 8.1 & & 29.2 & 11.9 & & 25.2 & 11.0 & & 24.7 & \\
\hline
\end{tabular}

herbicides ametrin, trifluralin, and imazapic. The herbicides [diuron + hexazinone + sulfometuron], clomazone, diclosulam, flumioxazin and imazapic provided satisfactory control of $\mathrm{P}$. maximum, even though only $50 \%$ of the dose was used, being the herbicide group with the best performance in this evaluation. In addition to these herbicides, amicarbazone, [diuron + hexazinone] $\mathrm{Fl}$, soxaflutole, sulfentrazone, and tebuthiuron were also found to have high levels of control when the $100 \%$ dose was used, being classified in the group of better treatments under these conditions.

The lower efficacy of herbicides after dry periods is due to these products when applied to the soil surface are often lost, especially if a prolonged dry period occurs after application (Silva et al., 2007). In addition, it is possible that losses occuras a function of the photodegradation process, as well as to other factors that may be involved, such as volatilization, accentuated by elevated soil surface temperature, chemical and biological degradation, and sorption, which should be considered to explain the disappearance of herbicides in soil (Silva et al., 2007; Monquero et al., 2008).
The results obtained for isoxaflutole in the present work are in agreement with some published papers, which indicate controls greater than $80 \%$ for this herbicide, even after 80 days of drought for $B$. decumbens and after 120 days of drought for P. maximum (Marchiori Jr. et al., 2005; Oliveira Jr. et al., 2006).

Digitaria horizontalis

All herbicides provided high control percentages for Digitaria horizontalis in the wet season at both doses and in both soils, except for s-metolachlor at the $50 \%$ dose in the sandy-clayloam soil (Table 4).

For the dry season, in the sandy-clayloam soil, only clomazone, [diuron + hexazinone + sulfometuron], diclosulam, flumioxazin and imazapic provided satisfactory control with the $50 \%$ dose. These same herbicides, with the addition of isoxaflutole and tebuthiuron, showed satisfactory control with the $100 \%$ dose.

In the very-clayey soil, the number of effective herbicides to control $D$. horizontalis was greater than in the sandy-clay-loam soil. Only hexazinone, isoxaflutole, and tebuthiuron were not effective when the $50 \%$ dose was used. At the $100 \%$ dose, only hexazinone showed control below $80 \%$. 
Table 4. Residual control of Digitaria horizontalis under 50 and $100 \%$ of the herbicides recommended dose for sugarcane crop, in the wet and dry season, in two soil textural classes at $30 \mathrm{DAl}$.

\begin{tabular}{|c|c|c|c|c|c|c|c|c|c|c|c|c|}
\hline \multirow{3}{*}{ Treatment } & \multicolumn{7}{|c|}{ Sandy-clay-loam soil } & \multicolumn{5}{|c|}{ Very clayey soil } \\
\hline & \multicolumn{3}{|c|}{$50 \%$} & \multicolumn{3}{|c|}{$100 \%$} & & & & \multicolumn{3}{|c|}{$50 \%$} \\
\hline & wet & & dry & & & wet & & dry & & wet & dry & \\
\hline 01-Control & 0.0 & c & $0.0 \mathrm{c}$ & 0.0 & $\mathrm{~b}$ & 0.0 & c & $0.0 \mathrm{~b}$ & $0.0 \mathrm{c}$ & $0.0 \mathrm{~b}$ & 0.0 & c \\
\hline 02-Amicarbazone & 100.0 & a & $10.0 \mathrm{c}$ & 100.0 & $a$ & 30.0 & $b$ & $100.0 \mathrm{a}$ & $81.7 \mathrm{a}$ & $100.0 \mathrm{a}$ & 96.7 & $a$ \\
\hline 03-Clomazone & 100.0 & a & $80.3 \mathrm{a}$ & 100.0 & $a$ & 93.3 & $a$ & $100.0 \mathrm{a}$ & $100.0 \mathrm{a}$ & $100.0 \mathrm{a}$ & 100.0 & a \\
\hline O4-[D+H] Fl1/ & 100.0 & $a$ & $33.0 \mathrm{~b}$ & 100.0 & $a$ & 30.3 & $b$ & $100.0 \mathrm{a}$ & $86.7 \mathrm{a}$ & $100.0 \mathrm{a}$ & 96.7 & $a$ \\
\hline $05-[\mathrm{D}+\mathrm{H}+\mathrm{S}]^{2 /}$ & 100.0 & a & $86.7 \mathrm{a}$ & 100.0 & $a$ & 81.7 & $a$ & 100.0 a & $100.0 \mathrm{a}$ & $100.0 \mathrm{a}$ & 100.0 & $a$ \\
\hline 06-Diclosulam & 100.0 & a & $85.0 \mathrm{a}$ & 100.0 & $a$ & 95.0 & $a$ & $95.7 \mathrm{a}$ & $97.0 \mathrm{a}$ & $95.7 \mathrm{a}$ & 100.0 & a \\
\hline 07-Flumioxazin & 100.0 & $a$ & $90.0 \mathrm{a}$ & 100.0 & $a$ & 80.0 & $a$ & $98.7 \mathrm{a}$ & $99.0 \mathrm{a}$ & $100.0 \mathrm{a}$ & 100.0 & $a$ \\
\hline 08-Hexazinona & 100.0 & a & $31.7 \mathrm{~b}$ & 100.0 & $a$ & 41.7 & $b$ & $98.7 \mathrm{a}$ & $68.3 \mathrm{~b}$ & $100.0 \mathrm{a}$ & 70.0 & $b$ \\
\hline 09-Imazapic & 100.0 & $a$ & $90.0 \mathrm{a}$ & 100.0 & $a$ & 100.0 & $a$ & $98.0 \mathrm{a}$ & $90.0 \mathrm{a}$ & $100.0 \mathrm{a}$ & 92.7 & $a$ \\
\hline 10-Isoxaflutole & 100.0 & $a$ & $46.7 \mathrm{~b}$ & 100.0 & $a$ & 81.7 & $a$ & $98.3 \mathrm{a}$ & $70.0 \mathrm{~b}$ & $100.0 \mathrm{a}$ & 91.7 & a \\
\hline 11-Sulfentrazone & 100.0 & $a$ & $38.3 \mathrm{~b}$ & 100.0 & $a$ & 50.0 & $\mathrm{~b}$ & $99.0 \mathrm{a}$ & $88.3 \mathrm{a}$ & $99.0 \mathrm{a}$ & 100.0 & $a$ \\
\hline 12-Tebuthiuron & 96.7 & $a$ & $26.7 \mathrm{~b}$ & 100.0 & $a$ & 90.0 & $a$ & $99.0 \mathrm{a}$ & $60.0 \mathrm{~b}$ & $100.0 \mathrm{a}$ & 88.7 & a \\
\hline 13-Ametrina & 100.0 & $a$ & - & 100.0 & $a$ & - & & $98.7 \mathrm{a}$ & - & $98.7 \mathrm{a}$ & - & \\
\hline $14-[\mathrm{D}+\mathrm{H}] \mathrm{F} 2^{3 /}$ & 100.0 & a & - & 100.0 & $a$ & - & & $100.0 \mathrm{a}$ & - & $100.0 \mathrm{a}$ & - & \\
\hline 15-Diuron & 100.0 & a & - & 100.0 & $a$ & - & & $100.0 \mathrm{a}$ & - & $91.7 \mathrm{a}$ & - & \\
\hline 16-Metribuzin & 100.0 & $a$ & - & 100.0 & $a$ & - & & $100.0 \mathrm{a}$ & - & $100.0 \mathrm{a}$ & - & \\
\hline 17-S-metolachlor & 77.3 & $b$ & - & 100.0 & $a$ & - & & $95.7 \mathrm{a}$ & - & $99.3 \mathrm{a}$ & - & \\
\hline 18-Trifluralin & 100.0 & $a$ & - & 100.0 & a & - & & $98.3 \mathrm{a}$ & - & $100.0 \mathrm{a}$ & - & \\
\hline $\bar{F}$ & 210.5 & & $27.2^{*}$ & 187.4 & & $24.2^{*}$ & & $208.2^{*}$ & $24.6^{*}$ & $267.2^{*}$ & $20.3^{*}$ & \\
\hline CV (\%) & 9.2 & & 26.3 & 4.9 & & 19.5 & & 4.67 & 28.7 & 11.1 & 24.2 & \\
\hline
\end{tabular}

Brachiaria plantaginea

The residual control of Brachiaria plantaginea in the wet season was very high in both soils and in both doses, excepted in the $50 \%$ s-metolachlor treatment (Table 5). For the dry season, in the sandy-clay-loam soil, the best options at the $50 \%$ dose were [diuron + hexazinon + sulfometuron], diclosulam, flumioxazin, isoxaflutole, and tebuthiuron. These herbicides were the best treatments on the control of $B$. plantaginea at the $100 \%$ dose, in addition to the imazapic.

In the very-clayey soil, there were more effective herbicide options in the control of B. plantaginea. Applying $50 \%$ of the dose, clomazone, [diuron + hexazinone] Fl, [diuron + hexazinone + sulfometuron] and diclosulamphoram were efficient. Applying 100\% of the dose, all herbicides were efficient except hexazinone, sulfentrazone, and tebuthiuron.

In agreement with these results, Carvalho et al. (2005) reported control of B. plantaginea and $D$. horizontalis above $90 \%$ with the application of $140 \mathrm{~g}$ i.a. ha $\mathrm{ha}^{-1}$ imazapic in the wet season at 60 days after application. Carbonari et al. (2009) also observed that amicarbazone at the dose of $1225 \mathrm{~g}$ i.a. ha $\mathrm{ha}^{-1}$ was effective in controlling B. plantaginea and Digitaria spp. at 42 days after application, in wet season conditions and up to 15 days of dry soil.

The results of the present study show that after 60 days of drought, there is low residual control using amicarbazone on B. plantaginea, which does not occur for Digitaria horizontalis. This was also verified by Carbonari et al. (2010), who observed a tendency of reduction in the control levels of clomazone + hexazinone on B. decumbens for periods over 60 days without rainfall, especially when applied on the straw and the soil, indicating that there is degradation of the products when subjected to extensive periods of exposure on the surface of the straw or soil without rainfall periods so that their distribution occurs in the soil profile.

The favorable result in very-clayey soils is possibly due to the fact that these herbicides are sorbed by the organic matter, clay minerals and metallic oxides of the soil (Monquero et al., 2008). While sorbed, the herbicides remain less exposed to degradation and transport processes, which may prolong the residual effect on the soil (Langenbach \& Correia, 2006). The 
Table 5. Residual control of Brachiaria plantaginea under 50 and $100 \%$ of the herbicides recommended dose for sugarcane crop, in the wet and dry season, in two soil textural classes at 30 DAl.

\begin{tabular}{|c|c|c|c|c|c|c|c|c|}
\hline \multirow{3}{*}{ Treatment } & \multicolumn{4}{|c|}{ Sandy-clay-loam soil } & \multicolumn{4}{|c|}{ Very clayey soil } \\
\hline & \multicolumn{2}{|c|}{$50 \%$} & \multicolumn{2}{|c|}{$100 \%$} & \multirow[b]{2}{*}{ dry } & & \multicolumn{2}{|c|}{$50 \%$} \\
\hline & wet & dry & & wet & & & wet & dry \\
\hline 01-Control & $0.0 \mathrm{c}$ & $0.0 \mathrm{c}$ & $0.00 \mathrm{~b}$ & $0.0 \mathrm{c}$ & $0.0 \mathrm{~b}$ & $0.0 \mathrm{c}$ & $0.0 \mathrm{~b}$ & $0.0 \mathrm{c}$ \\
\hline 02-Amicarbazone & 100.0 a & $7.0 \mathrm{c}$ & $100.0 \mathrm{a}$ & $10.0 \mathrm{c}$ & $100.0 \mathrm{a}$ & $20.0 \mathrm{c}$ & $100.0 \mathrm{a}$ & $93.3 \mathrm{a}$ \\
\hline 03-Clomazone & 100.0 a & $16.7 \mathrm{C}$ & $100.0 \mathrm{a}$ & $85.0 \mathrm{a}$ & $100.0 \mathrm{a}$ & $100.0 \mathrm{a}$ & $100.0 \mathrm{a}$ & $100.0 \mathrm{a}$ \\
\hline $04-[\mathrm{D}+\mathrm{H}] \mathrm{F}^{1 /}$ & 100.0 a & $10.0 \mathrm{C}$ & $100.0 \mathrm{a}$ & $23.3 \mathrm{~b}$ & $100.0 \mathrm{a}$ & $92.0 \mathrm{a}$ & $100.0 \mathrm{a}$ & $100.0 \mathrm{a}$ \\
\hline $05-[\mathrm{D}+\mathrm{H}+\mathrm{S}]^{2 /}$ & 100.0 a & $100.0 \mathrm{a}$ & 100.0 a & 100.0 a & $100.0 \mathrm{a}$ & $96.7 \mathrm{a}$ & $100.0 \mathrm{a}$ & $100.0 \mathrm{a}$ \\
\hline 06-Diclosulam & 100.0 a & $100.0 \mathrm{a}$ & $100.0 \mathrm{a}$ & $100.0 \mathrm{a}$ & $95.7 \mathrm{a}$ & $68.3 \mathrm{~b}$ & $95.7 \mathrm{a}$ & $95.0 \mathrm{a}$ \\
\hline 07-Flumioxazin & $100.0 \mathrm{a}$ & $93.0 \mathrm{a}$ & $100.0 \mathrm{a}$ & $100.0 \mathrm{a}$ & $98.7 \mathrm{a}$ & $95.0 \mathrm{a}$ & $100.0 \mathrm{a}$ & $100.0 \mathrm{a}$ \\
\hline 08-Hexazinona & 96.7 a & $10.0 \mathrm{c}$ & 100.0 a & $33.0 \mathrm{~b}$ & $98.7 \mathrm{a}$ & $0.0 \mathrm{c}$ & $100.0 \mathrm{a}$ & $63.3 \mathrm{~b}$ \\
\hline 09-Imazapic & 100.0 a & $61.7 \mathrm{~b}$ & $100.0 \mathrm{a}$ & $100.0 \mathrm{a}$ & $98.0 \mathrm{a}$ & $68.3 \mathrm{~b}$ & $100.0 \mathrm{a}$ & $100.0 \mathrm{a}$ \\
\hline 10-Isoxaflutole & 100.0 a & $80.0 \mathrm{a}$ & $100.0 \mathrm{a}$ & $90.0 \mathrm{a}$ & $98.3 \mathrm{a}$ & $53.3 \mathrm{~b}$ & $100.0 \mathrm{a}$ & $80.0 \mathrm{a}$ \\
\hline 11-Sulfentrazone & 100.0 a & $30.0 \mathrm{c}$ & $100.0 \mathrm{a}$ & $43.3 \mathrm{~b}$ & $99.0 \mathrm{a}$ & $50.0 \mathrm{~b}$ & $99.0 \mathrm{a}$ & $61.7 \mathrm{~b}$ \\
\hline 12-Tebuthiuron & 100.0 a & $80.0 \mathrm{a}$ & $100.0 \mathrm{a}$ & $86.7 \mathrm{a}$ & $99.0 \mathrm{a}$ & $0.0 \mathrm{c}$ & $100.0 \mathrm{a}$ & $59.3 \mathrm{~b}$ \\
\hline 13-Ametrina & 100.0 a & - & $100.0 \mathrm{a}$ & - & $98.7 \mathrm{a}$ & - & $98.7 \mathrm{a}$ & - \\
\hline $14-[\mathrm{D}+\mathrm{H}] \mathrm{F} 2^{3 /}$ & 100.0 a & - & $100.0 \mathrm{a}$ & - & $100.0 \mathrm{a}$ & - & $100.0 \mathrm{a}$ & - \\
\hline 15-Diuron & $100.0 \mathrm{a}$ & - & $100.0 \mathrm{a}$ & - & $100.0 \mathrm{a}$ & - & $99.3 \mathrm{a}$ & - \\
\hline 16-Metribuzin & 100.0 a & - & $100.0 \mathrm{a}$ & - & $97.3 a$ & - & $100.0 \mathrm{a}$ & - \\
\hline 17-S-metolachlor & $77.3 \mathrm{~b}$ & - & $100.0 \mathrm{a}$ & - & $95.7 \mathrm{a}$ & - & $99.3 \mathrm{a}$ & - \\
\hline 18-Trifluralin & 100.0 a & - & $100.0 \mathrm{a}$ & - & $98.3 a$ & - & $100.0 \mathrm{a}$ & - \\
\hline $\mathrm{F}$ & $1128.5^{*}$ & $25.7^{*}$ & $994.5^{*}$ & $19.9 *$ & $897.5^{*}$ & $26.2^{*}$ & $771.5^{*}$ & $24.6^{*}$ \\
\hline CV (\%) & 2.6 & 31.3 & 4.3 & 27.7 & 3.1 & 27.8 & 5.2 & 30.1 \\
\hline
\end{tabular}

sorption process slows or, in some cases, limits the movement and action of herbicides on the soil profile. However, after sorption, a fraction of the molecules can return to soil solution and can exert herbicidal activity, which is known as desorption (Bouchard et al., 1989; Inove et al., 2008).

On the other hand, the lower clay and organic matter content in the sandy-clay-loam soil contribute to the greater availability of the herbicide molecules in the soil solution, compared to the very-clayey soil, although there are numerous characteristics that interfere in sorption of herbicides to organic matter and soil colloids, such as the physicochemical characteristics of these products (Inove et al., 2014). In the case of clomazone, for example, it presents a low value of octanol-water partition coefficient, high water solubility in and lower affinity to soil organic matter (Silva et al., 2012). These characteristics make clomazone (Kow: 350, water solubility: 1100 $\mathrm{mg} \mathrm{L}^{-1}$ ) more likely to be present in the soil solution than other herbicides such as diuron, for example (Kow: 589; Solubility in water: 42 mg L-1).

According to Guimarães (1987), the characteristics that contribute to the maintenance of herbicide efficiency in the soil by periods of drought are low volatility, low photodegradability, high solubility, low sorption to soil colloids and degradation mainly by microorganisms, since in this condition many microorganisms present reduced their activity.

The herbicides evaluated in this work showed different performances as a function of the soil textural class, soil moisture, and weed species evaluated. For each combination of these factors, there were herbicides that showed better residual control performance, indicating that there is a better pre-emergence herbicide for each situation (Table 6).

In the wet season conditions, there were more effective herbicide options for pre-emergence control of these weeds. For B. plantaginea and D. horizontalis, there is no restriction regarding the treatment to be used, which does not occur for $B$. decumbens in very clayey soil and for P. maximum. On the other hand, in the dry season conditions, there is a greater restriction in the choice of treatment due to the lower effectiveness of some herbicides under these conditions. 
Table 6. Summary of herbicides most indicated for certain soil textural classes, period of the season and weed species considering $100 \%$ of the recommended dose.

\begin{tabular}{|c|c|c|c|c|}
\hline \multirow{2}{*}{ Species } & \multicolumn{2}{|c|}{ Wet season } & \multicolumn{2}{|c|}{ Dry season } \\
\hline & S.C.L. & V.C. & S.C.L. & V.C. \\
\hline $\begin{array}{l}\text { Brachiaria } \\
\text { decumbens }\end{array}$ & All herbicides & $\begin{array}{l}\text { All herbicides, } \\
\text { except } \\
\text { imazapic }\end{array}$ & $\begin{array}{c}\text { Clomazone, }[\mathrm{D}+\mathrm{H}+\mathrm{S}] \\
\text { diclosulam, flumioxazin and } \\
\text { isoxaflutole }\end{array}$ & $\begin{array}{c}\text { Amicarbazone, clomazone, } \\
{[D+H] \mathrm{Fl},[\mathrm{D}+\mathrm{H}+\mathrm{S}], \text { diclosulam, }} \\
\text { flumioxazin, isoxaflutole, } \\
\text { sulfentrazone and tebuthiuron }\end{array}$ \\
\hline $\begin{array}{c}\text { Brachiaria } \\
\text { plantaginea }\end{array}$ & All herbicides & All herbicides & $\begin{array}{c}{[\mathrm{D}+\mathrm{H}+\mathrm{S}] \text {, diclosulam, }} \\
\text { flumioxazin, imazapic, } \\
\text { isoxaflutole, clomazone and } \\
\text { tebuthiuron }\end{array}$ & $\begin{array}{l}\text { Amicarbazone, clomazone, } \\
{[\mathrm{D}+\mathrm{H}] \mathrm{Fl},[\mathrm{D}+\mathrm{H}+\mathrm{S}] \text {, diclosulam, }} \\
\text { flumioxazin, imazapic and } \\
\text { isoxaflutole }\end{array}$ \\
\hline $\begin{array}{c}\text { Digitaria } \\
\text { horizontalis }\end{array}$ & All herbicides & All herbicides & $\begin{array}{c}\text { Clomazone, }[\mathrm{D}+\mathrm{H}+\mathrm{S}] \\
\text { diclosulam, flumioxazin, } \\
\text { imazapic, isoxaflutole and } \\
\text { tebuthiuron }\end{array}$ & $\begin{array}{c}\text { Amicarbazone, clomazone, } \\
{[\mathrm{D}+\mathrm{H}] \mathrm{Fl},[\mathrm{D}+\mathrm{H}+\mathrm{S}] \text {, diclosulam, }} \\
\text { flumioxazin, imazapic, } \\
\text { isoxaflutole, sulfentrazone and } \\
\text { tebuthiuron }\end{array}$ \\
\hline $\begin{array}{l}\text { Panicum } \\
\text { maximum }\end{array}$ & $\begin{array}{l}\text { All herbicides, } \\
\text { except } \\
\text { sulfentrazone }\end{array}$ & $\begin{array}{c}\text { All herbicides, } \\
\text { expept } \\
\text { ametrina }\end{array}$ & $\begin{array}{c}\text { Clomazone, [D+H] Fl, } \\
\text { [D+H+S], diclosulam, } \\
\text { flumioxazin, hexazinona, } \\
\text { imazapic, isoxaflutole, } \\
\text { sulfentrazone and tebuthiuron }\end{array}$ & $\begin{array}{c}\text { Amicarbazone, clomazone, } \\
{[\mathrm{D}+\mathrm{H}] \mathrm{Fl},[\mathrm{D}+\mathrm{H}+\mathrm{S}] \text {, diclosulam, }} \\
\text { flumioxazin, imazapic, } \\
\text { isoxaflutole, sulfentrazone and } \\
\text { tebuthiuron }\end{array}$ \\
\hline
\end{tabular}

\section{Conclusions}

Under less dry conditions, as well as varying the soil textural class, there were restrictions on the choice of herbicide to be used, due to the lower effectiveness of some treatments in certain situations. On the whole, in the very clayey soil, especially in the dry season, herbicide efficacy is better, whereas for the dry season in the sandy-clay-loam soil the herbicide efficacy is restricted. Thus, the present study permitted to establish guidelines for decision making regarding the most suitable herbicides to be applied in each studied condition, aiming at the control of these weed species.

\section{References}

Azania, C.A.M., Rolim, J.C., Casagrande, A.A., Lavorenti, N.A., Azania, A.A.P.M. 2006. Seletividade de herbicidas. III - aplicação de herbicidas em pós-emergência inicial e tardia da cana-de-açúcar na época da estiagem. Planta Daninha 24: 489-495.

Azania, C.A.M., Azania, A.A.P.M., Pizzo, I.V., Schiavetto, A.R., Zera, F.S., Marcari, M.A., Santos, J.L.2009. Manejo químico de Convolvulaceae e Euphorbiaceae em cana-de-açúcar em período de estiagem. Planta Daninha 27: 841-848.

Bouchard, D.C., Enfield, C.G., Piwoni, M.D. 1989. Transport processes involving organic chemicals. In: Sawhney, B.L. (ed.). Reactions and movement of organic chemicals in soils. Soil Science Society of America, Madison,USA. p. 349-372.
Carbonari, C.A., Toledo, R.E.B., Velini, E.D., Negrisoli, E., Correa, M.R., Rossi, C.V.S. 2009. Efeitos de diferentes condições de umidade do solo e profundidades de germinação de Brachiaria plantaginea e Digitaria spp. sobre a eficácia do herbicida amicarbazone. Revista Brasileira de Herbicidas8: 68-74.

Carbonari, C.A., Velini, E.D., Correa, M.R., Negrisoli, E., Rossi, C.V., Oliveira, C.P.2010. Efeitos de períodos de permanência de clomazone + hexazinona no solo e na palha de cana-deaçúcar antes da ocorrência de chuvas na eficácia de controle de plantas daninhas. Planta Daninha28: 197-205.

Carvalho, S.J.P., Lombardi, B.P., Nicolai, M., López-Ovejero, R.F., Christoffoleti, P.J., Medeiros, D. 2005. Curvas de dose-resposta para avaliação do controle de fluxos de emergência de plantas daninhas pelo herbicida imazapic. Planta Daninha 23: 535-542.

CONAB. Companhia Nacional de Abastecimento. 2015. http://www.conab.gov. br/<Acesso em: 26/08/2015>.

Correia, N.M., Braz, B.A., Fuzita, W.E. 2010. Eficácia de herbicidas aplicados nas épocas seca e úmida para o controle de Merremia aegyptia na cultura da cana-de-açúcar. Planta Daninha 28: 631-642.

Guimarães, G.L. 1987. Impactos ecológicos do uso de herbicidas ao meio ambiente. Série Técnica IPEF 4: 159-180.

Hernandez, D.D., Alves, P.L.C.A., Martins, J.V.F. 2001. Influência do resíduo de colheita 
de cana-de-açúcar sem queima sobre a eficiência dos herbicidas imazapic e imazapic+pendimethalin. Planta Daninha 19: 419-426.

Inove, M.H., Possamai, A.C.S., Mendes, K.F., Ben, R., Matos, A.K.A., Santos, E.G. 2014. Potencial de lixiviação de herbicidas utilizados na canade-açúcar em solos contrastantes. Bioscience Journal 30: 659-665.

Inove, M.H., Oliveira Jr., R.S., Constantin, J., Alonso, D.G., Santana, D.C.2008. Lixiviação e degradação de diuron em dois solos de textura contrastante. Acta Scientiarum. Agronomy 30: 631-638.

Kuva, M.A., Pitelli, R.A., Salgado, T.P., Alves, P.L.C.A. 2007. Fitossociologia de comunidades de plantas daninhas em agroecossistema canacrua. Planta Daninha25: 501-511.

Langenbach, T., Correia, F. V. 2006. Dinâmica da distribuição e degradação de atrazina em Argissolo Vermelho Amarelo sob condições de clima tropical úmido. Revista Brasileira de Ciência do Solo 30: 1-10.

Marchiori Jr., O.,Constantin, J., Oliveira Jr., R.S., Inove, M.H., Pivetta, J.P., Cavalieri, S.D.2005. Efeito residual de isoxaflutole após diferentes períodos de seca. Planta Daninha 23: 491-499.

Monquero, P.A., Binha, D.P., Silva, A.C., Silva, P.V., Amaral, L.R. 2008. Eficiência de herbicidas pré-emergentes após períodos de seca. Planta Daninha 26: 185-193.

Negrisoli, E., Velini, E.D., Corrêa, M.R., Rossi, C.V.S., Carbonari, C.A., Costa, A.G.F., Perim, L. 2011. Influência da palha e da simulação de chuva sobre a eficácia da mistura formulada clomazone + hexazinone no controle de plantas daninhas em área de cana-crua. Planta Daninha 29: 169-177.

Oliveira Jr., R.S., Marchiori Jr., O., Constantin, J., Inove, M.H. 2006. Influência do período de restrição hídrica na atividade residual de isoxaflutole no solo. Planta Daninha 24: 733-740.

Silva, A.A., Ferreira, F.A., Ferreira, L.R. 2007. Herbicidas: classificação e mecanismo de ação. In: Silva, A. A, Silva, J. F. (eds.) Tópicos em manejo de plantas daninhas. Universidade Federal de Viçosa, Viçosa, Brasil. p. 83-147.

Silva, M.S., Cocenza, D.S., Rosa, A.H., Fraceto, L.F. 2012. Efeito da associação do herbicida clomazone a nanoesferas de alginato/quitosana na sorção em solos. Química Nova 35: 102-107. 